Vincent, J.-S. 1983: La géologie du Quaternaire et la géomorphologie de L'île Banks, Arctique Canadien. Mem. geol. Surv. Can. 405, 118 pp.

Vincent, J.-S., Morris, W. A. \& Occhietti, S. in press: Glacial and nonglacial sediments of Matuyama paleomagnetic age on Banks Island, Canadian Arctic Archipelago. Geology.

S. F. \& O. B.,

Geologisk Museum,

Øster Voldgade 5-7,

DK-1350 Copenhagen $K$.

G. S. M.,

Botanisk Museum,

Gothersgade 130,

DK-1123 Copenhagen $K$.

S. A. S. P.,

Geologisk Centralinstitut,

$\emptyset$ ster Voldgade 10 ,

DK-1350 Copenhagen $K$.
B. N. $-N$,

Biologisk Institut,

Odense Universitet,

Campusvej 55

6000 Odense,

Denmark.

K. S. P.,

Danmarks Geologiske Undersøgelse

Thoravej 31 DK-2400 Copenhagen NV.

\title{
Programme NordGrøn (PNG) 1983-1985: regional mapping and geological studies in western and central North Greenland
}

\author{
Peter R. Dawes
}

Programme NordGrøn (PNG) is planned as an onshore, regional mapping, and stratigraphic and structural study of the ice-free areas of northern Greenland between Humboldt Gletscher in the south-west $\left(80^{\circ} \mathrm{N}\right)$ and western Peary Land to the east $\left(c .45^{\circ} \mathrm{W}\right)-$ a region of about $45000 \mathrm{~km}^{2}$ (fig. 8). It is a sequel to the three-year programme carried out farther to the east in North Greenland in 1978-1980 (Peary Land to Kronprins Christian Land, see Henriksen, 1979, 1980, 1981 and GGU Reports 88 (1979), 99 (1980), 106 (1981). PNG is scheduled as a two-summer geological field activity in 1984 and 1985; in the summer of 1983, a three-man group visited the region to undertake logistic preparation and reconnaissance studies.

\section{Logistics}

The field activity will take place in June, July and August, with the main geological investigations concentrated in a period of nine to ten weeks. The activity will be carried out by 12 to 13 two-man geological teams, and some 14 support personnel including base camp staff and helicopter and fixed-wing crews - a total of about 40 participants per season. The field work will be supported by two small helicopters (Bell 206 Jet Rangers or Hughes 500) and a DHC-6 Twin Otter. 

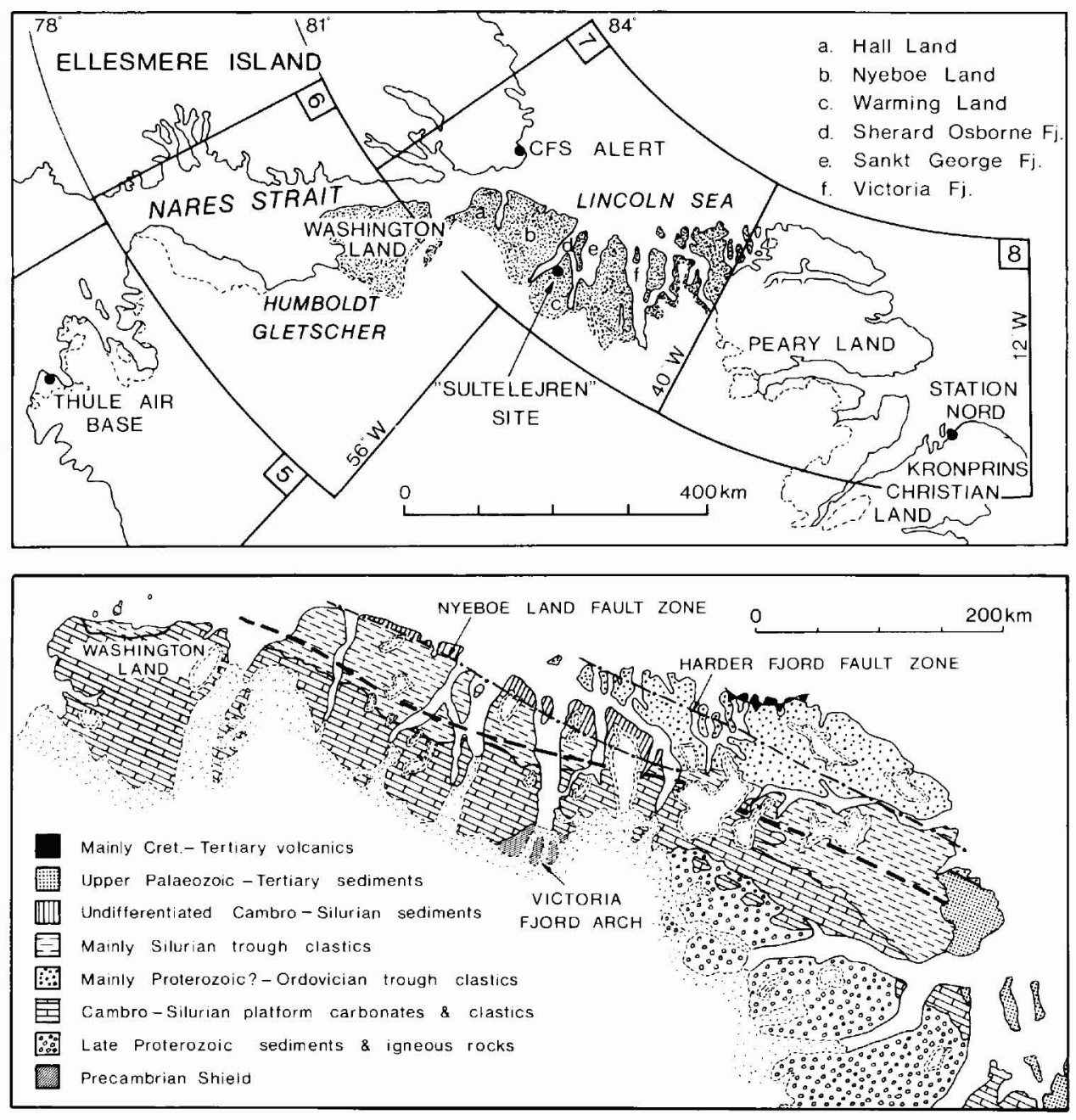

Fig. 8. Maps of northern Greenland. Above: Location map showing the Programme NordGrøn (PNG) study region (stippled) and the outline of the Survey's 1:500 000 map sheets (numbered frames). Below: Geological map of the PNG region and land to the east, showing the localities of the Nyeboe Land fault zone, Harder Fjord fault zone and the Victoria Fjord arch. Broken line marks the southern boundary of the North Greenland fold belt. Geology from GGU Reports 88 (1979), 99 (1980), 106 (1981), and the Nares Strait volume, Meddr Grønland, Geosci. 8, 1982.

Access to the study region will be through Thule Air Base (TAB) in North-West Greenland and Station Nord in eastern North Greenland while the Canadian Forces Station (CFS) at Alert, on the north-eastern coast of Ellesmere Island (Canada), will act as the main mobilising base (fig.8). The field operations will be directed from a base camp in Warming Land.

PNG is supported by the Royal Danish Air Force, and heavy cargo and fuel will be 
transported by RDAF C-130 Hercules aircraft. Aviation fuel is made available by the U.S. Air Force at TAB; the Canadian Forces and the Polar Continental Shelf Project (Ottawa) have provided facilities at CFS Alert.

\section{Finance}

The total field budget per season represents a very high proportion of GGU's aggregate field budget. Part of the sedimentological basin analysis and petroleum geology studies, including the source-rock and drilling programme, is organised as a project supported financially by the Ministry of Energy. The difficult logistic position of North Greenland with ice-locked seas all year round, makes transport by air essential. Aircraft charter and aviation fuel costs amount to about $75 \%$ of the field budget.

\section{General geology}

The PNG study region exposes a cross-section through an ancient continental margin. The Precambrian craton is flanked to the north by a major, Lower Palaeozoic sedimentary basin - the Franklinian geosyncline. This E-W linear, sedimentary tract comprises two geologic terrains: in the south a shallow-water carbonate shelf having an exposed contact with the Precambrian shield (of which only about $100 \mathrm{~km}^{2}$ are exposed adjacent to the Inland Ice), and in the north a deep-water clastic trough (fig. 8). The northern part of the trough now constitutes the deformed and low-metamorphic North Greenland fold belt in which rocks at least as young as latest Silurian (Pridoli - possibly extending into the Devonian) have been recognised (Berry et al., 1974; Hurst \& Surlyk, 1982). The deformation and metamorphism of the fold belt are referred to the mid-Palaeozoic (Devonian-Carboniferous) and Cenozoic (Tertiary) orogenies known to have affected adjacent regions to the east (Peary Land), and to the west in Arctic Canada (Ellesmere Island). Apart from an isolated outcrop of Palaeogene or Neogene deposits in Washington Land (Jepsen, 1982), no strata equivalent in age to the Carboniferous to Tertiary sequences of the Sverdrup Basin (Arctic Canada) or the Wandel Sea Basin (Greenland) have yet been recorded in this part of North Greenland. It is thus difficult to accurately date the tectonic regimes that affected the region and to differentiate fully between the Palaeozoic and Tertiary structural elements.

\section{Aim of Programme NordGrøn}

The main aim of PNG is to undertake systematic geological mapping and stratigraphicstructural studies, as well as to make a preliminary assessment of the economic geology of the region. The work forms part of the Survey's 1:500 000 mapping campaign and the study region covers a single 1:500 000 map sheet (Lincoln Sea, no. 7), and parts of a second sheet to the south-west (no. 6) (fig. 8). Map compilation will be mainly at 1:100 000 and more detailed studies at special targets are planned.

The economic assessment will involve a wide range of integrated studies in stratigraphy, petrology, palaeontology, sedimentology, structural geology, economic mineralogy, geochemistry and petroleum geology. Work in the latter will include a regional reservoir potential study and source-rock analysis based on material obtained by a shallow-drilling programme. Palaeomagnetic, glaciological, and surficial studies are also planned. 
The major north-south trending fjords that dissect the PNG study region at right angles to the regional geological trends, provide a special opportunity to carry out a detailed stratigraphic and structural analysis across a classic continental margin from stable craton to shelf and slope, and into a deformed deep-water trough. The steep fjord walls and the wellexposed geology facilitate the construction of accurate cross-sections and isometric fence diagrams to elucidate the geology of the ancient continental margin. The stratigraphical, sedimentological and palaeontological studies, including the analysis and mapping of the various sedimentary facies of the Proterozoic? and Lower Palaeozoic sequences, will be used in a comprehensive platform-basin evolutionary synthesis. The structural studies will involve the mapping and analysis of the syn- and post-sedimentary tectonic elements, both within the metamorphosed and folded rocks of the North Greenland fold belt and in the homoclinal strata to the south.

Special attention will be directed to prominent structural features such as the Nyeboe Land and Harder Fjord fault zones which are extensive dislocetions in the North Greenland fold belt, and the Victoria Fjord arch - a salient of Precambrian shield projecting northwards into the E-W sedimentary tracts of the Franklinian geosyncline (fig. 8). Some uncertainty centres on the nature and tectonic history of these features and on the extent to which they, or in the case of the fault zones their precursors, have affected the sedimentary evolution of the platform and deep-water basin (Surlyk et al., 1980; Higgins et al., 1981; Dawes, 1982; Håkansson \& Pedersen, 1982; Surlyk \& Hurst, 1983; Hurst et al., 1983). The platform basin boundary was not a static feature during the Lower Palaeozoic. Detailed studies should determine to what extent faulting has affected or controlled the location, type and development of the platform margin and the shelf-slope-trough configuration, and, moreover, what effects the varying location of the platform margin has had on the style and trends of the structures of the North Greenland fold belt.

Potential targets in the search for outcrops of 'young' (post-Franklinian) strata, equivalent in age to the Upper Palaeozoic - Mesozoic - Tertiary deposits of the Sverdrup Basin and Wandel Sea Basin, must be the faulted areas like the Nyeboe Land and Harder Fjord fault zones. The discovery of such 'young' rocks would not only be significant in itself but would also be of the utmost importance for the elucidation of the region's late Phanerozoic tectonic history and the distinction of this history from the earlier Palaeozoic structural framework.

\section{Regional implications}

The PNG study region in western and central North Greenland lies geographically between, and on geological strike with, eastern and western segments of the Franklinian geosyncline in Peary Land and Ellesmere Island. A number of outstanding geological problems in the region have important regional implications. The integrated interdisciplinary studies to be carried out in conjunction with the systematic geological mapping activity will contribute to the understanding of the early crustal evolution and basin development of the Innuitian region.

There can be no doubt that North Greenland and Ellesmere Island developed as proximal parts of the same crustal plate. There is a marked similarity in the Lower Palaeozoic platform and basin evolution in both regions, and specific stratigraphic and structural elements have been used in a detailed spatial comparison of the two areas across Nares Strait (see Dawes \& Kerr, 1982). Detailed investigation of the PNG region will lead to a more 
precise definition of the so-called 'geological markers' which will help to assess their use as tools for determining the relative palaeogeographic position of Greenland and Ellesmere Island.

\section{3 laboratory work}

The planning of GGU's geological mapping campaign in North Greenland showed the need to improve the quality of the existing topographical maps (for summary, see Dawes, 1977; Dueholm, 1979). Aerial photography and a ground surveying programme were undertaken in 1978-1980 by the Geodetic Institute, Copenhagen, to produce a new topographic map series to replace the American AMS 1:250 000 maps that had been drawn on the basis of post-war trimetrogon aerial photographs by the Army Map Service. The new Danish coverage of North Greenland will take the form of contoured orthophotographic map sheets at 1:100 000. However, the production of this map series is not yet completed.

In preparation for the 1984 field work and to assist in the compilation of all existing published and unpublished geological data, a computer-supported programme, based on the recent Danish aerial photography, was started in GGU's photogeological laboratory in 1983. 1:150 000 scale diapositives are being used in the exercise that involves the drawing out of a contoured map at 1:100 000, as well as a regional geological photo-interpretation. The western part of the PNG region, Washington Land and Hall Land, is not included in this laboratory study, since both areas have been the subject of recent geological and geodetic projects (see Dawes, 1977; Peel, 1977; Dueholm, 1979). Coloured geological map sheets of both lands at 1:250 000 and $c .1: 66000$, respectively, are in the process of publication.

The photogrammetric topographical-geological mapping is being carried out with a Kern PG2 stereo-plotting instrument with a semi-automatic drawing table, equipped with a Hewlett-Packard calculator and display terminal. The orientation of the stereoscopic models, as well as the topographic contouring is being carried out by photogrammetric operator O. Winding, while the geological interpretation and compilation, including stratigraphical and structural measurement and analysis by computer programme, is being undertaken by J. C. Escher, A. K. Higgins and H. F. Jepsen.

\section{3 field work}

In a four-week period in July and August a three-man group carried out various geological reconnaissance and logistic tasks in the PNG study region, including the establishment at CFS Alert of a large fuel and equipment cache on which the 1984 field activity will be based. Freight was carried from Denmark to Station Nord by a RDAF C-130 Hercules and a C-160 Transall (French Air Force) aircraft, and to Thule Air Base by ship. Ten RDAF C-130 landings were made at CFS Alert and about 42500 U.S. gallons (160000 litres) of JP-4 fuel and about 17 tons of equipment were cached (fig. 9).

A Twin Otter aircraft from Flugfélag Norðurlands hf., Iceland, was used to carry out geological reconnaissance of the coastal sections of Sankt George Fjord, Sherard Osborne Fjord and Victoria Fjord (fig. 8), as well as over the Quaternary deposits of central Hall Land. Black and white photography (about 500 exposures) was undertaken along the wellexposed steep fjord walls with a hand-held Mamiya 645 camera with motorised film transport and automatic exposure. The purpose of this photography was to document the 


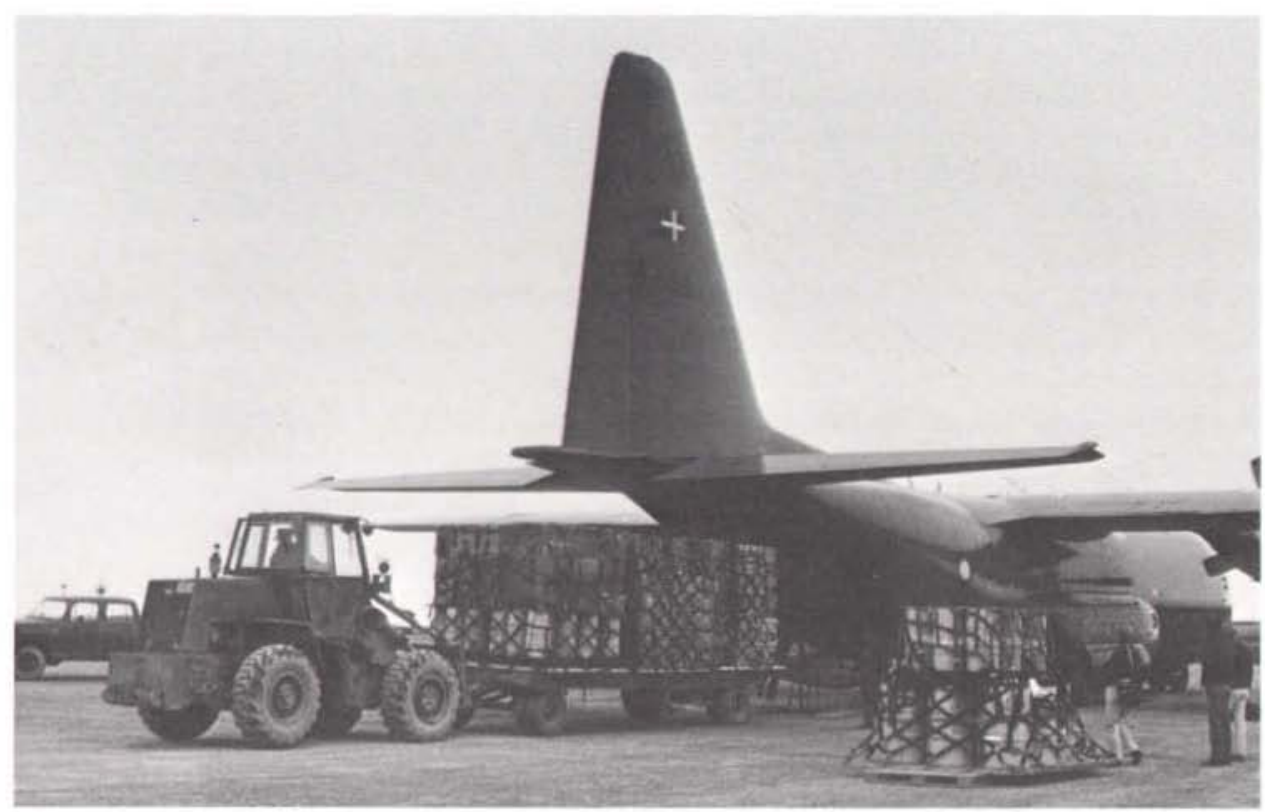

Fig. 9. RDAF C-130 Hercules on the apron at CFS Alert unloading supplies during the 1983 logistic prepartion of Programme NordGron.

stratigraphic and structural detail along a S-N transect from the unfolded platform into the deformed northern trough sequence. The photographic material is being used in a preliminary geological interpretation and in map compilation of the study region mentioned in the previous section; this will form the basis of the pending field work. Some fjord-wall profiles were photographed with a $20 \%$ exposure overlap in an attempt to produce oblique stereoscopic material of sufficient quality for accurate geological measurement by computersupported photogrammetric techniques.

The Twin Otter was also used to visit several locations in the PNG study region; to check and replenish supply caches, and to investigate the logistic potential of the so-called 'Sultelejren' base camp site in north-western Warming Land. A good landing strip at least $550 \mathrm{~m}$ long on a dry gravel river terrace was located at the site where there is also room for a cross strip. The main strip requires only light shovel work; $350 \mathrm{~m}$ were prepared, marked and tested. An adequate water supply to support a base camp exists at the site.

Acknowledgements. The 1983 field work was undertaken with the help and assistance of Palle Bay and Jørgen Lau, as well as numerous other persons and institutions. The author is grateful to the following: Dept. of National Defence Headquarters, Ottawa, for permission to use facilities at CFS Alert and for transport by Canadian Forces C-130 aircraft; Major Tom Hanway, Commanding Officer CFS Alert and Commander Erik V. Johansen, Danish Liaison Officer, Thule Air Base, for support, assistance and hospitality; Major J. F. Clemmensen, Royal Danish Air Force, for support and cooperation with the C-130 fuel and cargo lift and for liaison in the use of a C-160 aircraft of the French Air Force; U. S. Air 
Force and its representatives at Thule Air Base for service and facilities; Director George Hobson, Polar Continental Shelf Project, Ottawa, for advice and use of facilities at Alert; Major Poul Ancker, Meteorological Institute, Copenhagen, for cooperation in the use of Twin Otter aircraft; and the personnel of the Sirius sledge patrol at Station Nord for hospitality and indispensable help in handling and packing heavy equipment.

\section{References}

Berry, W. B. N., Boucot, A. J., Dawes, P. R. \& Peel, J. S. 1974: Late Silurian and early Devonian graptolites from North Greenland. Rapp. Grønlands geol. Unders. 65, 11-13.

Dawes, P. R. 1977: Geological photo-interpretation of Hall Land: part of the regional topographicalgeological mapping of northern Greenland. Rapp. Grønlands geol. Unders. 85, 25-30.

Dawes, P. R. 1982: The Nyeboe Land fault zone: a major dislocation on the Greenland coast along northern Nares Strait. In Dawes, P. R. \& Kerr, J. W. (edit.) Nares Strait and the drift of Greenland: a conflict in plate tectonics. Meddr Grønland, Geosci. 8, 177-192.

Dawes, P. R. \& Kerr. J. W. (edit.) 1982: Nares Strait and the drift of Greenland: a conflict in plate tectonics. Meddr Grønland, Geosci. 8, 396 pp.

Dueholm, K. S. 1979: Geological and topographical mapping from aerial photographs. Meddr Inst. Surv. Photogrammetry, Danm. Tekn. Højsk. 10, 9-146.

Håkansson, E. \& Pedersen, S. A. S. 1982: Late Paleozoic to Tertiary tectonic evolution of the continental margin in North Greenland. In Embry, A. F. \& Balkwill, H. R. (edit.) Arctic geology and geophysics. Mem. Can. Soc. Petrol. Geol. 8, 331-348.

Henriksen, N. 1979: Systematic 1:500 000 mapping in the Peary Land region, North Greenland. Rapp. Grønlands geol. Unders. 95, 9-13.

Henriksen, N. 1980: Systematic 1:500 000 mapping in the Peary Land region, North Greenland. Rapp. Grønlands geol. Unders. 100, 11-15.

Henriksen, N. 1981: Systematic 1:500 000 mapping in the Peary Land region, North Greenland. Rapp. Grønlands geol. Unders. 105, 9-14.

Higgins, A. K., Friderichsen, J. D. \& Soper, N. J. 1981: The North Greenland fold belt between central Johannes V. Jensen Land and eastern Nansen Land. Rapp. Grønlands geol. Unders. 106, 35-45.

Hurst, J. M., McKerrow, W. S., Soper, N. J. \& Surlyk, F. 1983: The relationship between Caledonian nappe tectonics and Silurian turbidite deposition in North Greenland. J. geol. Soc. Lond. 140, 123132.

Hurst, J. M. \& Surlyk, F. 1982: Stratigraphy of the Silurian turbidite sequence of North Greenland. Bull. Grønlands geol. Unders. 145, $121 \mathrm{pp}$.

Jepsen, H. F. 1982: The Bjørnehiet Formation: a faulted preglacial conglomerate, Washington Land, North Greenland. In Dawes, P. R. \& Kerr J. W. (edit.) Nares Strait and the drift of Greenland: a conflict in plate tectonics. Meddr Grønland, Geosci. 8, 151-155.

Peel, J. S. 1977: Cambrian-Silurian studies in Washington Land, western North Greenland. Rapp. Grønlands geol. Unders. 85, 30-33.

Surlyk, F. \& Hurst, J. M. 1983: Evolution of the early Paleozoic deep-water basin of North Greenlandaulacogen or narrow ocean? Geology 11, 77-86.

Surlyk, F., Hurst, J. M. \& Bjerreskov, M. 1980: First age-diagnostic fossils from the central part of the North Greenland foldbelt. Nature, Lond. 286, 800-803. 